\title{
O CORPO, O COMER E A COMIDA: UM ESTUDO SOBRE AS PRÁTICAS CORPORAIS E ALIMENTARES NO MUNDO CONTEMPORÂNEO
}

\author{
Food, Eating, and the Body: A Study about Eating and \\ Body Practices in the Contemporary World
}

\author{
Heloise Peratello*
}

\begin{abstract}
SANTOS, L. A. da S. O corpo, o comer e a comida: um estudo sobre as práticas corporais e alimentares no mundo contemporâneo. Salvador: EDUFBA, 2008.
\end{abstract}

Em uma conhecida citação, a antropóloga Mary Douglas afirmou que o corpo é uma forma simbólica, na qual as normas centrais, as hierarquias e os comprometimentos culturais são reforçados e reproduzidos. Esta noção foi também compartilhada por importantes pensadores do século XX. Mas o que faz com que o corpo se torne importante objeto de investigação para a História e para as Ciências Sociais?

O estudo desenvolvido por Lígia Amparo da Silva Santos - que resultou no livro $\mathrm{O}$ corpo, o comer e a comida: um estudo sobre as práticas corporais e alimentares no mundo contemporâneo, publicado em 2008 - nos oferece algumas pistas a respeito do lugar central ocupado pelos corpos na contemporaneidade e por uma das formas mais tradicionais de transformação física: as dietas alimentares. Professora da Universidade Federal da Bahia, com formação em Nutrição, Educação Física e especialização em Ciências Sociais, Santos procura conduzir a análise de forma interdisciplinar, apontando para as múltiplas redes de discursos e mentalidades que operam sobre as formas corporais e culminam em efetivas práticas cotidianas.

Apesar do interesse que os dois temas suscitam, a interseção entre corpo e alimentação é pouco explorada no cenário acadêmico brasileiro. Santos consegue oferecer tanto a análise da situação soteropolitana quanto

Mestre em História pela Universidade Federal do Paraná. 
a sistematização teórica e metodológica para pensar tal relação. Embora a metodologia seja de natureza antropológica, a autora procura reconhecer e localizar elementos que compõem o corpo e a alimentação de modo historicamente situado. Para ela, as experiências de homens e mulheres, suas formas de sentir e agir e o processo de modernização das cidades e dos comportamentos estão intimamente ligados à mudança de hábitos e à incorporação de novos modelos alimentares. Santos acredita na construção de uma nova ordem, que procura uma espécie de valorização da existência leve, refletida em corpos magros, ágeis e eficientes.

A transformação de corpos com base em técnicas disciplinares, como observou Thomas Laqueur ${ }^{1}$, torna o controle uma das principais ferramentas para a sua consagração. Assim, as práticas alimentares são profundamente afetadas para satisfazer aos ideais de saúde e beleza, tornando o consumo restritivo de alimentos uma das características da forma como homens e mulheres se relacionam com a comida.

No capítulo I, ao fazer uma reflexão sobre a tríade corpo, comer e comida, Santos menciona o trabalho de estudiosos como Claude Fischler, Annie Hubert e Jean-Pierre Poulain para demonstrar que as práticas alimentares são socialmente construídas e possuem a marca identitária da cultura de uma sociedade. Portanto, as características contemporâneas trariam importantes indícios de seu tempo, tais como o individualismo, o hedonismo e as técnicas científicas de aperfeiçoamento. Os universos temáticos do corpo belo, saudável, do cuidado de si e das representações da comida e do comer são explorados como formas de problematizar este corpo e a comida que o alimenta. Em relação ao controle alimentar, Santos relembra a presença das mais variadas dietas em todos os tempos, nem sempre ligadas à perda de peso. Restrições alimentares são estimuladas por motivações que podem se relacionar à religião, às crenças, à moral e à saúde, caracterizando seus múltiplos usos e funções. Na atualidade, a dieta tem a ciência como discurso fundador, o controle como aliado e a ideia utópica de dieta humana perfeita para se atingir a boa saúde e o corpo belo.

Santos reserva ao capítulo II a discussão sobre as escolhas metodológicas e os recortes necessários para o tratamento do objeto tendo como eixo central a cidade de Salvador, as transformações urbanas e a fala dos

1 LAQUEUR, Thomas. Inventando o sexo. Rio de Janeiro: Relume Dumará, 2001. 
entrevistados. Por trabalhar com relatos, a autora não definiu recortes predeterminados, mas sim, chegou ao universo empírico, por meio das questões colocadas pelo próprio objeto. No capítulo III, Santos relata a trajetória dos entrevistados para reconstruir as motivações que os levaram a promover mudanças nas próprias práticas corporais e alimentares. Neste momento, ela relaciona as histórias individuais aos elementos contemporâneos, às variações sociais e aos aspectos circunscritos ao cenário soteropolitano.

$\mathrm{O}$ capítulo IV é dedicado à atividade física enquanto prática. Ao imergir na fala dos entrevistados, Santos vai desenhando as representações que são dadas à morfologia do corpo e às influências que recaem, remodelam e conformam os padrões físicos desenvolvidos em meio à idolatria do músculo bem definido e ao pavor causado pela gordura. Estas foram questões encontradas nas entrevistas e interpretadas pela autora como situações que se desenvolveram baseadas em influências da mídia e da disseminação de imagens que interferem nos corpos de homens e mulheres de maneira diferenciada. Para ela, tais influências minimizam as resistências e permanências culturais da cidade de Salvador e a tradição alimentar local, conformando todos os corpos dentro de padrões semelhantes aos mesmos padrões nacionais e internacionais.

O capítulo $\mathrm{V}$ é dedicado a outra estratégia de transformação corporal: a alimentação. Santos procura verificar na fala dos entrevistados, as continuidades e mudanças nas práticas alimentares para compreender as influências da própria modernização da cidade e as mudanças nas mentalidades dos indivíduos. Ela elege algumas questões fundamentais: a noção da ação reflexiva sobre a comida, aliada à cacofonia alimentar, ou seja, ao excesso de informações que cercam o universo do comer, o processo de reaprendizagem sobre a comida, o controle dos desejos, e a reestruturação do gosto, pautada muitas vezes pelas preocupações estéticas e dietéticas. O impacto destas situações para a redefinição das sensibilidades gustativas contribui para a disseminação de novos significados simbólicos do alimento e para a relação entre os indivíduos e o comer.

Santos acredita que esta nova sensibilidade esteja ligada ao modelo de vida light. Tal perspectiva é desenvolvida no capítulo VI, com a interpretação dos dados coletados, e revela o quanto a mudança sobre a forma de pensar o corpo pode impactar na alimentação. A determinação de novas disciplinas corporais e alimentares institui, necessariamente, a formação 
de uma nova culinária. Para demonstrar isso, a autora mergulha no universo alimentar, nas mudanças das preparações culinárias, nas escolhas dos gêneros alimentícios, sem deixar de comentar sobre o acarajé e a feijoada baiana. Neste contexto, as representações sobre os alimentos passam a ser pautadas pela difusão científica do conhecimento sobre os nutrientes e a consequente classificação entre bons e ruins, saudáveis ou nocivos.

O principal mérito da obra de Santos é escolher importantes elementos de análise para a compreensão das práticas alimentares no contexto contemporâneo e soteropolitano. Embora restrito a Salvador, o estudo nos força a repensar o papel dos indivíduos para as escolhas alimentares, já que este indivíduo é formado em meio a inúmeras redes discursivas e é agente de constantes mudanças cotidianas, que muitas vezes deixam de lado as constantes permanências e tradições ligadas à alimentação.

Recebido em agosto de 2010. Aprovado em agosto de 2010. 